\title{
Correlation between Postpartum Traditions and the Process of Uterine Involution
}

\author{
Indria Nuraini* \\ Midwifery, FIKes, PGRI Adi Buana University, Surabaya, East Java, Indonesia \\ *indria@unipasby.ac.id
}

\begin{abstract}
Postpartum is a risky period for complications, wherein almost $60 \%$ of maternal deaths occur after childbirth and $50 \%$ of maternal deaths occur in the first 24 hours after childbirth. Factors that cause complications during postpartum period are anemia, personal hygiene, fatigue and childbirth history, such as prolonged labor, PROM, or traumatic labor. Indonesia is a large country consisting of islands along with various tribes and different cultural backgrounds, which affect people's behavior, including health behavior. Socio-Cultural aspect in the community has a positive or negative influence on health behavior during the postpartum period which includes beliefs in abstinence, taboos, and recommendations for certain beliefs related to Postpartum. This study aims to determine the correlation between postpartum traditions and the process of uterine involution at Private Practice Midwife Dominggas M.L.S.O Surabaya. This was an observational descriptive study with the cross sectional design. This study site was conducted at Private Practice Midwife Domingas M.L.S.O Sidotopo Wetan. The population in this study were all women in postpartum Days 3-10. The samples were chosen with Total Sampling Technique. Data were analyzed using Chi Square test. The results showed that 14 respondents $(36,8 \%)$ respondents did not practice postpartum traditions and had normal Uterine Involution. The result of data analysis using Chi Square obtained $(\rho=0.744)$. It can be concluded that there was no correlation between Postpartum Traditions and Uterine Involution.
\end{abstract}

Keywords: PostPartum, Tradision, Uterine Involution. 


\section{STRADA Jurnal Ilmiah Kesehatan}

DOI: $10.30994 /$ sjik.v9i2.261

ISSN: 2252-3847 (print); 2614-350X (online)

Vol.9 No.2 November 2020 Page.412-419

\section{BACKGROUND}

Socio-cultural aspect or tradition greatly influences the pattern of human life. In the era of globalization with various extreme changes, all humans are required to pay attention to the socio-cultural aspects. One of the problems that is indirectly influenced by social, cultural and environmental aspects in the community is the Maternal and Child Mortality or Morbidity (Maas, 2004). The latest maternal mortality rate in Surabaya is $85.72 / 100,000$ live births. Maternal deaths occur during pregnancy, childbirth and postpartum. The number of maternal deaths in 2016 was 37, wherein 6 (16.2\%) occurred during pregnancy, $7(18.9 \%)$ occurred during childbirth and 24 people (64.9\%) occurred during postpartum (Surabaya City Health Office, 2016). Causes of Maternal Death were Pre Eclampsia (30.90\%), Bleeding (28.65\%), Others $(24.72 \%)$, Heart Disease $(10.86 \%)$ and Infection (4.87\%). (Dinas Kesehatan Provinsi Jawa Timur, 2016). In Developing Countries, the indirect causes of maternal deaths are lack of health facilities, delayed assistance, and community education (Manuaba, 2008). The problem of maternal mortality or morbidity is inseparable from the socio-cultural factors that exist in the community in the form of concepts about various taboos, the relationship between food and health, habits or knowledge that may affect maternal health (Khasanah, 2011). Surabaya is the second metropolitan city in Indonesia where the population consists of various ethnic and cultural groups, and there are indigenous people or migrants. Apparently, the dense of development to the swift influence of globalization are not able to eliminate the beliefs and culture that adversely affect Postpartum women. Such culture cannot be eradicated, one of the powerful reasons is because several beliefs/myths of Postpartum women are proofen to be true. However, on the other hand, there are some beliefs/myths that do not bring a positive impact for Postpartum women and also to the newborn babies. Research conducted by austiyana with exploring information about rituals and culture during pregnancy, childbirth and postpartum in kalisari bojonegoro. The results obtained in this study that during childbirth such as drinking herbal medicine, eating lunch, using curved, doing treatments such as the use of pilis, tapel or parem (Austiyana, 2004). Based on these problems the authors are interested to determine the Correlationship between Postpartum Traditions and Uterine Involution Process.

\section{METHODS}

This was an observational descriptive with the Cross Sectional approach, wherein the variables included in the risk factors and variables included in the effects are observed at the same time. The population in this study were all women in postpartum Days 3-10. The samples were chosen with Total Sampling Technique. The independent variables in this study were Postpartum Traditions while the Dependent Variable was Uterine Involution. This study was conducted at Private Practice Midwife Domingas M.L.S.O in Sidotopo Wetan Surabaya in August to October 2019. Data collection technique used a closed questionnaire for Postpartum Traditions as well as an observation sheet to assess the Uterine Involution. Questionnaire in this study using standardized instruments so that no validity and reliability tests were performed. After all data were collected, Editing, Tabulating, Coding and Analysis of data were done using the Chie Square Test.

This study has obtained Ethical Clearance from Health Research Ethics Committee of the Ministry of Health of Semarang No.008/EA/KEPK/2020. 


\section{STRADA Jurnal Ilmiah Kesehatan}

DOI: $10.30994 /$ sjik.v9i2.261

ISSN: 2252-3847 (print); 2614-350X (online)

Vol.9 No.2 November 2020 Page.412-419

\section{RESULT}

Characteristics of respondents to postpartum traditions

Table 1. Frequency distribution of respondents characteristics with postpartum tradisitions and Involution uteri

\begin{tabular}{lcccccccc}
\hline \multirow{2}{*}{ Characteristic } & \multicolumn{3}{c}{ Postpartum Tradisions } & \multicolumn{3}{c}{ Involution Uteri } \\
\cline { 2 - 10 } & $\begin{array}{c}\text { Was not } \\
\text { practiced }\end{array}$ & \multicolumn{2}{c}{ Practiced } & Conform & \multicolumn{2}{c}{$\begin{array}{c}\text { Not } \\
\text { Confirm }\end{array}$} \\
\cline { 2 - 10 } & $\mathrm{N}$ & $\mathrm{F}(\%)$ & $\mathrm{N}$ & $\mathrm{F}(\%)$ & $\mathrm{N}$ & $\mathrm{F}(\%)$ & $\mathrm{N}$ & $(\%)$ \\
\hline Age : & & & & & & & & \\
<20 years old & 0 & 0 & $\mathbf{3}$ & $\mathbf{7 , 9}$ & $\mathbf{1}$ & 2,6 & $\mathbf{2}$ & $\mathbf{5 , 3}$ \\
20-35 years old & 15 & 39,5 & 11 & 28,9 & 15 & 39,5 & 11 & 28,9 \\
>35 years old & 4 & 10,5 & 5 & 13,2 & 5 & 13,2 & 4 & 10,5 \\
Education : & & & & & & & & \\
Elementary & 1 & 2,6 & 3 & 7,9 & 1 & 2,6 & 3 & 7,9 \\
school & 2 & 5,3 & $\mathbf{6}$ & 15,8 & 5 & 13,2 & $\mathbf{3}$ & $\mathbf{7 . 9}$ \\
Middle School & 14 & 36,8 & 10 & 26,3 & 14 & 36,8 & 10 & 26,3 \\
High School & 2 & 5,3 & 0 & 0 & 1 & 2,6 & 1 & 2,6 \\
College & & & & & & & & \\
Parity : & & & & & & & & \\
Primipara & 8 & 21,1 & $\mathbf{7}$ & 18,4 & 10 & 26,8 & $\mathbf{5}$ & $\mathbf{1 3 , 2}$ \\
Multipara & $\mathbf{1 1}$ & 28,9 & 10 & 26,3 & 15 & 39,5 & $\mathbf{6}$ & $\mathbf{1 5 , 8}$ \\
Grandepara & $\mathbf{2}$ & 5,3 & 0 & 0 & 0 & 0 & $\mathbf{2}$ & $\mathbf{5 , 3}$ \\
Type of work: & & & & & & & & \\
Housewife & 7 & 18,4 & $\mathbf{1 4}$ & 36,8 & 11 & 28,9 & $\mathbf{1 0}$ & $\mathbf{2 6 , 8}$ \\
The Employee & 2 & 5,3 & 2 & 5,3 & 2 & 5,3 & 2 & 5,3 \\
Private & $\mathbf{1 0}$ & 26,3 & $\mathbf{3}$ & 7,9 & 8 & 21,1 & $\mathbf{5}$ & 13,2 \\
\hline
\end{tabular}

The results of the study of the authors' attention are the first characteristics of age with a carried out postpartum tradition and uterine involution, at the age $<20$ years ( 3 respondents) did postpartum tradition, one respondent involuntary uterine according to the puerperium and two respondents were not appropriate. Secondly, education found respondents with junior high school education (six respondents), carried out the tradition, 3 respondents involuntarily inappropriate, and 2 respondents following the postpartum period. Third parity, on this characteristic there are seven respondents practice the puerperal tradition and uterine involution is not confirm (5 respondents) and multipara found 11 puerperal women don't carry out the puerperal tradition but uterine involution isn't confirmed (6 clients) and 2 grande para don't carry out the puerperal culture and involution the uterus isn't coming down. Fourth on work, post-partum mothers with jobs in the private sector and not carrying out postpartum culture (10 clients), two postpartum mothers decreased uterine fundus height isn't appropriate whereas in housewives who carry out traditions but their uterine involution is appropriate (4 clients) 


\section{STRADA Jurnal Ilmiah Kesehatan}

DOI: $10.30994 /$ sjik.v9i2.261

ISSN: 2252-3847 (print); 2614-350X (online)

Vol.9 No.2 November 2020 Page.412-419

Table 2. Characteristics of respondents with postpartum traditions

\begin{tabular}{lccc}
\hline \multirow{2}{*}{ Characteristic } & \multicolumn{3}{c}{ Postpartum Traditions } \\
\cline { 2 - 4 } & Care & Nutrition & Rest \\
\hline Age & $\rho=0.063$ & $\rho=0.051$ & $\rho=0.576$ \\
Education & $\rho=0.530$ & $\rho=0.089$ & $\rho=0.045$ \\
Parity & $\rho=0.303$ & $\rho=0.09$ & $\rho=0.146$ \\
Type of work & $\rho=0.471$ & $\rho=0.292$ & $\rho=0.087$ \\
\hline
\end{tabular}

The Results of the traditional approach after giving birth to the characteristics of respondents found that postpartum care has a strong relationship with the age of the respondent $(0,063)$. For the tradition of nutrition (abstinence from food and consuming herbal medicine ) related to age $(0,051)$, whereas from limiting significant rest to education level $(0,045)$.

\section{Correlation Between Postpartum Tradition and Uterine Involution} Table 3. Cross Tabulation of the Correlation between Postpartum Traditions and Uterine Involution

\begin{tabular}{|c|c|c|c|c|c|}
\hline \multirow[t]{3}{*}{ Tradition } & \multicolumn{4}{|c|}{ Uterine Involution } & \multirow{3}{*}{ Chi Square } \\
\hline & \multicolumn{2}{|c|}{ Conform } & \multicolumn{2}{|c|}{ Not conform } & \\
\hline & $\mathrm{N}$ & $\mathrm{F}$ & $\mathrm{N}$ & F & \\
\hline Nutrition & & & & & 0.548 \\
\hline Was not practiced & 14 & 36.8 & 8 & 21.1 & \\
\hline Practiced & 7 & 18.4 & 9 & 23.7 & \\
\hline Rest & & & & & 0.498 \\
\hline Was not practiced & 14 & 36.8 & 9 & 23.7 & \\
\hline Practiced & 7 & 18.4 & 8 & 21.1 & \\
\hline Care & & & & & 0.303 \\
\hline Was not practiced & 14 & 36.8 & 13 & 34.3 & \\
\hline Practiced & 7 & 18.4 & 4 & 10.5 & \\
\hline Tradition $><$ Uterine Involution & & & & & 0.744 \\
\hline
\end{tabular}

In the above study, most respondents did not practice culture after childbirth and uterine involution proceeded quickly both in term of nutrition, rest and care as many as 14 respondents $(36,8 \%)$. In the study explained that there were 7 respondents practicing abstinence with uterine involution following the puerperium $(18,4 \%)$ and 9 respondents abstinence and uterine involution process did not match the puerperium $(23,7 \%)$, obtained $(\mathrm{p}=0,548)$. On the culture of resting restriction, 15 respondents run, 7 people with appropriate involution $(18,4 \%)$ and 8 with uterine involution process not according to the puerperium $(21,1 \%)(\mathrm{p}=0,498)$. For childbirth care, there are 11 respondents runnings a culture of postpartum care, 7 respondent with involution according to the puerperium $(18,4 \%)$ and 4 respondents with uterine involution are not appropriate $(p=0,303)$. So it can be concluded that there is no relations between the puerperal tradition and the process of uterine involution $(\mathrm{p}=0,744)$ 


\section{STRADA Jurnal Ilmiah Kesehatan}

DOI: $10.30994 /$ sjik.v9i2.261

ISSN: 2252-3847 (print); 2614-350X (online)

Vol.9 No.2 November 2020 Page.412-419

\section{DISCUSSION}

\section{Characteristics of respondents to postpartum tradisions}

Based on the characteristics of respondents, there was no aspect that had an effect on postaprtum care, variable that was close to the postpartum care tradition was age $(\rho=0.063)$. Postpartum care includes the use of stagen/corset/bekung, the use of tapel/bobok (herbs applied on the abdominal skin), pilis (herbs applied on the forehead), concoction on the stitches and massage. According to Notoadmodjo, behavior performed in postpartum care is influenced by predisposing factors, such as age, parity, education, type of work, knowledge, attitude, and culture. Age is a benchmark for the development of learning abilities and is a teaching of behavior. Physical, psychological and cognitive maturity is influenced by age. Maturity of one's development can be obtained from one's own experience or from others (Lestari, 2016). In te study conducted by Maryati (2018), all postpartum women performed traditional treatments such as using herbs for topical and drinking, massage, warm compress and abstinence from food practice without being influenced by education, occupation, age or ethnicity (Mariyati and Tumansery, 2018).

There was a significant relationship between postpartum traditions and age from the perspective of nutrition $(\rho=0.051)$. The traditions related to nutrition in this study were the abstinence from food and herbal medicine consumption. According to Foster and Anderson (1986), eating habits in a society can be influenced by culture. This belief concerns the type of food and how to prepare and consume food (Dinar Angraini, 2013). The results of this study contradict to the opinion of Larasati (2009), wherein the postpartum women behavior namely abstinence from food of was influenced by factors of education, social economy, culture and the role of health workers (Nugraheni and Dyah, 2013). The effect of age on the behavior of postpartum women regarding the abstinence from food is due to the development of the women's mindset or comprehension. This is due to the fact that most respondents were multiparous women (more than one child). Increasing age will make the development of mindset and comprehension, so that postpartum women were able to distinguish foods that could benefit mothers and their babies (Endah and Rizkyana, 2014).

There was a significant relationship between education and postpartum traditions from the perspective of rest $(\rho=0.045)$. A person's knowledge can be influenced by education, work, age, interests, experience, culture and information. The higher a person's education, the easier she is to get information, so that attitudes toward receiving new information and values will develop rapidly (Mubarak, 2011). The results of data collection through interviews found that the majority of respondents had high school education and practice the tradition of not napping. This is in line with a study conducted at the Sragen Community Health Center that postpartum women did not take a nap because of belief or myth (Rahayuningsih, 2013). This contradicts the opinion of Anggraini (2010), where postpartum women should increase the period of rest during the day (Rahayuningsih, 2013). It can be concluded that the culture in the neighborhood had a big role in the formation of attitudes regarding postpartum traditions despite the high education level of postpartum women.

\section{Correlation between Postpartum Traditions and Uterine Involution}

From table 3 it was explained that most of respondents did not practice postpartum traditions namely traditions regarding nutrition, rest and postpartum care. Thus, there was no strong correlation between postpartum traditions and the process of uterine involution 


\section{STRADA Jurnal Ilmiah Kesehatan}

DOI: $10.30994 /$ sjik.v9i2.261

ISSN: 2252-3847 (print); 2614-350X (online)

Vol.9 No.2 November 2020 Page.412-419

$(\rho=0.744)$.

Postpartum tradition is a view of life or the actions conducted by a society or group from generation to generation (which becomes a habit) in the form of all things regarding postpartum. This may include food restriction (fish, meat or eggs), drinking herbs or the use of stagen or bengkung. (Roichana and Pratiwi, 2013).

In the above study there were 16 respondents who practiced postpartum tradition of abstinence from protein (eggs, fish and meat), 9 respondents had uterine involution process that was not conform to postpartum age. This is in accordance with the opinion of Pitrianai (2014) that uterine muscles will be weak if the nutritional needs of postpartum women, especially carbohydrates and proteins are not met. Nutrition in postpartum women serves as a source of health recovery and helps increase breast milk production (Muthoharoh, 2018). The above study also found that respondents who practiced the tradition of abstinence from food but had quick uterine involutio. This was found in Primiparous respondents ( 7 respondents) and on the other hand there were multiparous and grand-multiparous respondents ( 8 respondents) who did not practice the tradition of abstinence but had slow Uterine Involution. The results of this study are in accordance with the opinion of Palupi that parity had an effect on the process of uterine involution, the less number of children born, the faster the process of involution. This process is caused by muscle stretching and abdominal elasticity(Palupi, 2011). According to Neeson \& Mai (1986), the uterine contractions is stronger and the Uterine Fundal is harder in primiparous women, while in multiparpous women had weaker contractions and longer uterine relaxation (Hadi and Martini, 2014).

The tradition of rest restriction was found in 15 respondents who did not take a nap during the day. Among them, 8 respondents had slow uterine involution (did not conform to the postpartum age) and 7 respondents had fundal height that was conform to postpartum age. Rest is very needed by postpartum women to help the healing and recovery processes and to assist the production of breast milk (Bahiyatun, 2009). According to Suhana (2010) lack of rest/sleep in postpartum women can cause several adverse effects namely reduced breast milk production, slow uterine involution, until post partum blues or depression (Fatmawati and Hidayah, 2019). In this study, there were also respondents who practiced a tradition of rest restriction during the day but the Fundal height decreased more quickly, this was because the women provided exclusive breastfeeding to their baby. The breastfeeding process stimulates the release of the oxytocin hormone that triggers uterine contractions (uterine involution process). (Wulan and Patonah, 2010).

The traditions of puerperium care include the use of stagen or bengkung, the use of a tapel applied on the abdominal skin and pilis applied on the forehead. It was found that 11 respondents practiced postpartum care, among them 7 respondents had normal uterine involution (conform to the postpartum age) and 4 respondents had slow uterine involution. The results of the interview showed that most of respondents practiced care using a stagen or corset or bengkung. In a study conducted by Maryani (2012) stagen or bengkung only disguise the mother's abdomen after giving birth so that it did not directly affect the health of postpartum women. Furthermore, according to a study conducted by Rahayu (2017), the use of stagen or bengkung had not effect on the involution process, however, the involution process was strongly influenced by parity (Rahayu, 2017). A study conducted by El-Mekawy, et al (2013) showed that abdominal exercise program can manage diastasis recti, promote a reduction in abdominal circumference and a better 


\section{STRADA Jurnal Ilmiah Kesehatan}

DOI: $10.30994 /$ sjik.v9i2.261

ISSN: 2252-3847 (print); 2614-350X (online)

Vol.9 No.2 November 2020 Page.412-419

increase in abdominal muscles strength compared to using an abdominal belt (ElMekawy et al., 2013). Exclusive breastfeeding helps uterine fundal height whereas puerperal care with the use of a bengkung/stagen/corset doesn't directly assist uterine involution but only disguises the abdomen. Efforts can be made to help accelerate the decline in the height of the fundus uterine by doing exercises such as puerperal gymnastics.

\section{CONCLUTION}

It can be concluded that the traditions parcticed by postpartum women namely abstinence from food, napping restriction during the daytime and postpartum care using stagen or corset or bengkung had no effect on the process of uterine involution

\section{REFERENCES}

Austiyana, M. (2004) 'Tingkeban, brokohan, selapanan'. Available at: http://amma.socsci.uva.nl/theses/austiyana, m. (2004).pdf.

Bahiyatun (2009) Buku Ajar Kebidanan Nifas Normal. Jakarta: EGC.

Dinar Angraini (2013) 'Pantangan Makan Ibu Hamil dan Pasca Melahirkan di Desa Bongkot Kecamatan Peterongan Kabupaten Jombang'. Jurnal BioKultur.

Dinas Kesehatan Kota Surabaya (2016) 'Profil Kesehatan Tahun 2016'. Available at: http://www.depkes.go.id/resources/download/profil/PROFIL_KAB_KOTA_201 6/3578_Jatim_Kota_Surabaya_2016.pdf.

Dinas Kesehatan Provinsi Jawa Timur (2016) 'Profil Kesehatan Provinsi Jawa Timur Tahun 2016'. Available at: http://www.depkes.go.id/resources/download/profil/PROFIL_KES_PROVINSI_ 2016/15_Jatim_2016.pdf.

El-Mekawy, H. et al. (2013) 'Effect of Abdominal Exercises versus Abdominal Supporting Belt on Post-Partum Abdominal Efficiency and Rectus Separation', International Science Index, 7(1), pp. 44-48. Available at: http://waset.org/journals/waset/v73/v73-136.pdf

Endah, E. and Rizkyana, S. (2014) 'Hubungan Pola Nutrisi Ibu Post Partum dengan Penyembuhan Luka Jahitan Perineum di Wilayah Kerja Puskesmas Bajulmati Kabupaten Banyuwangi', Jurnal Healthy, 3(1), pp. 49-58.

Fatmawati, R. and Hidayah, N. (2019) 'Gambaran Pola Tidur Ibu Nifas', Journal Infokes, 9(2), pp. 44-47.

Hadi, Y. and Martini, M. (2014) 'FAKTOR- FAKTOR YANG BERHUBUNGAN DENGAN INVOLUSI UTERUS PADA IBU POST PARTUM DI WILAYAH KERJA PUSKESMAS KETAPANG LAMPUNG UTARA', Journal Kesehatan Metro Sai Wawai, VII(2), pp. 2-8. 


\section{STRADA Jurnal Ilmiah Kesehatan}

DOI: $10.30994 /$ sjik.v9i2.261

ISSN: 2252-3847 (print); 2614-350X (online)

Vol.9 No.2 November 2020 Page.412-419

Khasanah, N. (2011) 'Dampak Persepsi Budaya terhadap Kesehatan Reproduksi Ibu dan Anak di Indonesia’, pp. 487-492.

Lestari, P. (2016) 'Usia Berpengaruh Dominan terhadap Perilaku Perawatan Luka Perineum pada Ibu Nifas di RSUD Sleman Postpartum Women Hospital Sleman', pp. 95-101.

Maas, L. T. (2004) 'Digitized by USU digital library 1', pp. 1-6.

Manuaba, I. G. (2008) Gawat Darurat Obstetri Ginekologi dan Obstetri Ginekologi Sosial untuk Profesi Bidan. Jakarta: EGC.

Mariyati and Tumansery, G. S. (2018) 'Perawatan diri berbasis budaya selama masa nifas pada ibu postpartum'.

Mubarak, W. I. (2011) Promosi Kesehatan untuk Kebidanan. Jakarta: Salemba Medika.

Muthoharoh, H. (2018) 'Hubungan Pantang Makanan Pada Ibu Nifas Dengan Percepatan Involusi Uterus Pada Hari Ke 7 Post Partum', Jurnal Kebidanan, 10(1), p. 9. doi: 10.30736/midpro.v10i1.59.

Nugraheni, I. and Dyah, P. (2013) 'Perilaku Pantang Makanan pada Ibu Nifas di Wilayah Kerja Puskesmas Bayat Klaten’, Jurnal Infokes, 3(2), pp. 12-24.

Palupi, I. F. H. (2011) 'Hubungan Inisiasi Menyusui Dini dengan Perubahan Involusi Uteri pada Ibu Nifas di BPS Anik S, Amd.Keb di Mojosongo Surakarta', ejournal.stikesmhk.ac.id.

Rahayu, D. T. (2017) 'Efektivitas Bengkung dan Gurita terhadap Involusi Uteri dan Pengeluaran Lochea di Puskesmas Keling Kabupaten Kediri', Jurnal Ilmu Keperawatan dan Kebidanan, III(4).

Rahayuningsih, F. B. (2013) 'Hubungan Aktivitas Ibu Nifas Dengan Kualitas Hidup Ibu Nifas Di Wilayah Puskesmas Miri Sragen', prosiding konferensi nasional PPNI jawa tengah 2013, pp. 37-40.

Roichana, S. and Pratiwi, Y. A. (2013) 'Hubungan Senam Nifas, Mobilisasi Dini, dan Tradisi Masa Nifas terhadap Proses Involusi Uteri pada Ibu Post Partum', Journal Ilmiah Kebidanan Indonesia, 2014, pp. 2-31.

Wulan, F. and Patonah, S. (2010) 'Pengaruh Menyusui Terhadap Penurunan Tinggi Fundus Uteri Pada Ibu Post Partum Primigravida Di RSUD DR.R. Sosodoro Djatikoesoemo Bojonegoro', Jurnal Ilmiah Ilmu Kebidanan dan Keperawatan, 1(1), pp. 27-32. 